\title{
Geothermal Salt Factory (GSF) Design in Parangwedang Geothermal, Bantul, Special Region of Yogyakarta
}

\author{
Alfian Gilang ${ }^{1 *}$, Mohammad H. Jauhari ${ }^{2}$, Maria T. Kristiati ${ }^{2}$ \\ ${ }^{I}$ Geological Engineering, UPN “Veteran” Yogyakarta \\ Ngropoh, Sleman, Yogyakarta 55281, Indonesia \\ ${ }^{2}$ Petroleum Engineering, UPN "Veteran" Yogyakarta \\ Jl. SWK 104 Condongcatur, Sleman, Yogyakarta 55281, Indonesia
}

Received 29 June 2020; Accepted 13 August 2020

Available online 31 August 2020

\begin{abstract}
Indonesia has the largest geothermal energy potential in the world with potential value $\pm 28 \mathrm{GWe}$, but the potential of geothermal low enthalpy is still not utilized properly. On the other hand, improvement in the salt industry needs to be done because the salt industry in Indonesia has not been able to meet domestic salt demand. Domestic salt supply deficit is caused by the salt industry in Indonesia just relies on salt traditional farmers who are very dependent on the sunlight and the absence of a modern and sustainable salt-making industry. Therefore, the authors made a salt factory design using low enthalpy geothermal by utilizing Parangwedang geothermal as a heat source energy. Parangwedang geothermal is located in the Special Region of Yogyakarta with existence manifestation as a hot spring. Based on previous research, the potential of Parangwedang geothermal was 10 MWe. The reservoir rock may have a temperature range $115^{\circ} \mathrm{C}$ and the hot spring fluid temperature $43{ }^{\circ} \mathrm{C}$. The hot spring distance from the seashore is 403 meters with elevation reach 8 meters. The method used in this study is literature study and data collection in the field. Literature data is obtained from various sources and then compiled and grouped for the design of the salt factory that utilizes low enthalpy geothermal energy. This factory system will involve two pumps, one of which will drain the hot water from the Parangwedang hot spring and the other will drain the water from the ocean to the salt production pan. A boiling tank and condenser are used to boil the sea. Hot water from the boiling tank is used for drying the salt brine and brine is dried in the salt pan. In the result, the authors calculated factory production capacity, the GSF production capacity is \pm 14 tons salt each year.
\end{abstract}

Keywords: low enthalpy geothermal, salt factory, Parangwedang Hot Spring

\section{Introduction}

Indonesia is one of the countries that have the largest potential of geothermal energy in the world with a potential of 11,073 MW and reserves of 17,506 MW (ESDM, 2017), this potential energy still needs to be exploited to meet energy diversification in Indonesia in accordance with Presidential Regulation No. 5/2006 about the National Energy Policy that geothermal energy in 2025 has a role of 5\% on national energy consumption. There are two types of geothermal energy utilization models, namely indirect use of geothermal energy high enthalpy and direct use of geothermal low enthalpy. In Indonesia, indirect use is used for electricity generation while direct use is only used for hot spring tourism, so the potential of geothermal low enthalpy in Indonesia is still not utilized properly (Hassan, 2009).

On the other hand, Indonesia still needs to modernize in the industrial field, one of which is the salt industry. Salt is Indonesia's strategic commodity whose demand continues to increase along with the increase in population (Jami et al., 2017), modernization in the salt industry needs to be done due to salt production in Indonesia not yet able to meet domestic salt needs. Referring to the Ministry of Trade's data in 2018 during January-February Indonesia's salt imports have reached 299,000 tons. The main

\footnotetext{
* Corresponding author

E-mail address: alfianggilangg@gmail.com
} 
cause of the domestic salt supply deficit lies in the Indonesian salt-making industry which relies solely on traditional pond farmers who are too dependent on climate and weather (Jami et al., 2017). Therefore, the researchers propose making FGSF a low enthalpy geothermal salt producer.

One of the low enthalpy geothermal fields in Indonesia is the Parangwedang geothermal field, Bantul, DIY whose manifestations are located at $8^{\circ} 01$ '27.26' 'south latitude and $110^{\circ} 19^{\prime} 40.84$ 'east longitude, and $\pm 74 \mathrm{~m}$ from the shoreline. GSF was designed in Parangtritis by utilizing geothermal energy from the Parangwedang hot spring. This proposal will describe the geological review of Parangwedang hot springs, design, work mechanism and estimated production capacity of GSF (Geothermal Salt Factory).

\section{Theory}

\subsection{Low Enthalpy Geothermal Utilization in Indonesia}

The 300 low-high enthalpy locations that have been identified in Indonesia (Fauzi, 2015), their utilization is still far from 5\%. In fact, Presidential Regulation No. 5/2006, mandates that in 2025 geothermal energy has a role of 5\% of national energy consumption. In addition, the use of low enthalpy geothermal energy in Indonesia is still very minimal (Table 1), most of which are only used for hot water baths and water tourism, whose benefits are still very low for the economy, even though enthalpy low heat can be used for various things, one of which is for energy salt factory.

Table 1. Classification of the distribution of geothermal energy in Indonesia (Fauzi, 2015).

\begin{tabular}{|l|r|r|}
\hline \multirow{2}{*}{ Location } & \multicolumn{2}{|c|}{ Classification (Mwe) } \\
\cline { 2 - 3 } & $\begin{array}{c}\text { Low enthalphy } \\
<100-190^{\circ} \mathrm{C}\end{array}$ & $\begin{array}{c}\text { High enthalpy } \\
>190{ }^{\circ} \mathrm{C}\end{array}$ \\
\hline Sumatra & 2,951 & 8,636 \\
\hline Jawa \& Bali & 1,663 & 5,373 \\
\hline Nusa Tenggara & 862 & 537 \\
\hline Kalimantan & 145 & - \\
\hline Sulawesi & 1,696 & 1,146 \\
\hline $\begin{array}{l}\text { Maluku \& } \\
\text { Papua }\end{array}$ & 569 & 442 \\
\hline Total & $\mathbf{7 , 8 8 6}$ & $\mathbf{1 6 , 1 3 4}$ \\
\hline
\end{tabular}

\subsection{Parangwedang Low Enthalpy Geothermal Potential}

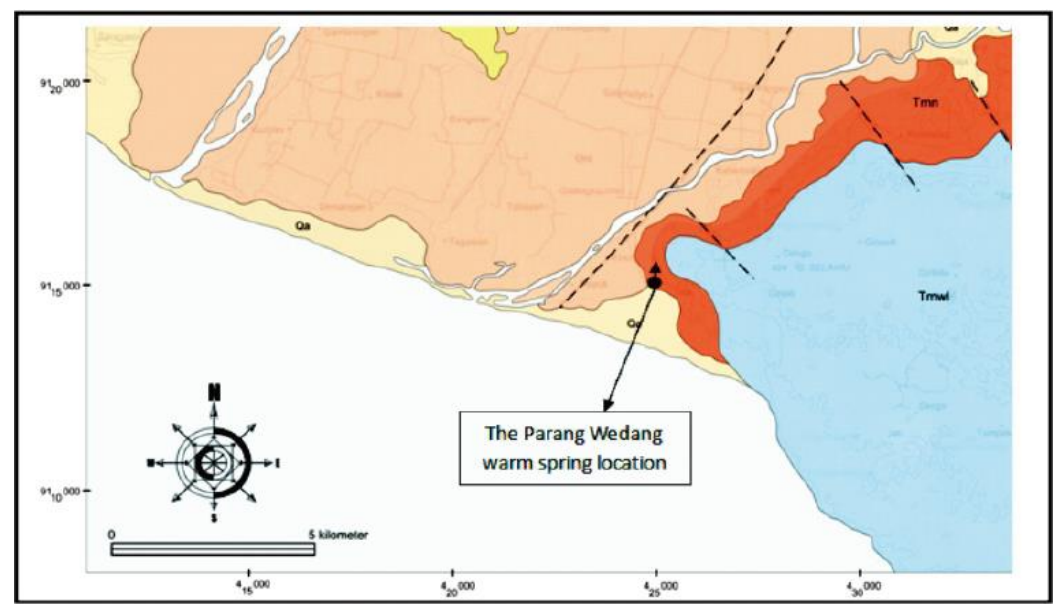

Figure 1. Surface geological map of the Parang Wedang area showing the distribution of lithologies, faults and warm springs (Restu, 2016).

The stratigraphy of Parangtritis and its surrounding areas is composed of Tertiary rocks such as volcanic clastic sedimentary rocks, volcanic rocks, and carbonate clastic sediments, and Quaternary sediments 
(Idral et al., 2003). The pattern of geological structures is mostly related to the tectonic event in the Java Trench, including a major NE-SW normal fault, called Opak normal fault (Figure 1). Additionally, there are also SE-NW Bantul normal fault and NE-SW Parangkusumo strike-slip fault around the Parang Wedang, The Parangkusumo fault, showing strike of $\mathrm{N} 300^{\circ} \mathrm{W}$ and dip of $80^{\circ}$ (Juliarka, et al., 2016).

The manifestation of Parangwedang is located $\pm 403 \mathrm{~m}$ from the shoreline with elevation $\pm 8 \mathrm{~m}$ above sea level. In a previous investigation, it was known that hot water tastes salty, colorless, odorless, neutral $\mathrm{pH}$ (7.49), surface temperature $49^{\circ} \mathrm{C}$ at air temperature $28.2^{\circ} \mathrm{C}$, while sub-surface temperature based on geo-thermometer $\mathrm{SiO}_{2}$ is estimated at $\pm 115{ }^{\circ} \mathrm{C}$ (Idral et al., 2003). Based on the $\mathrm{SiO}_{2}$ (ac) geothermometer, the estimation of the subsurface temperature is around $115^{\circ} \mathrm{C}$ which is included in the low enthalpy. With an estimate of the prospect of around $4 \mathrm{~km}^{2}$ from the results of pseudo-type resistance and with a cut-off temperature of $90{ }^{\circ} \mathrm{C}$, and with the formula:

$$
\mathrm{Q}=0.2317 \times \mathrm{A} \times(\text { Tag }- \text { Tcut-off })
$$

So, the potential of Parangtritis geothermal resources is around $10 \mathrm{MWe}$ with geothermal reservoir depth at $600 \mathrm{~m}$ (Idral et al., 2003).

\subsection{Indonesia Salt Production Conditions}

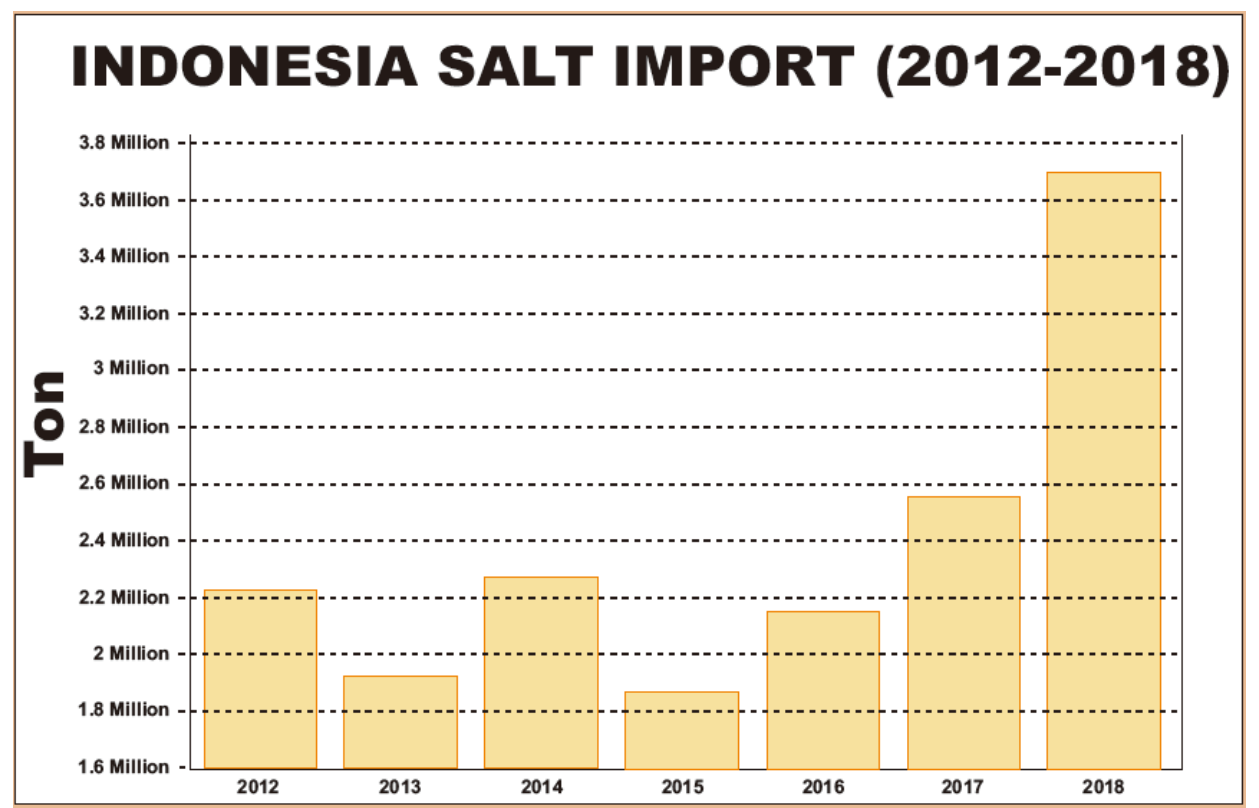

Figure 2. Indonesia salt import 2010-2017 (Modification from BPS, 2019).

The Indonesian government always imports salt annually to meet domestic salt needs, this is because Indonesia only relies on traditional salt farmers who only depend on weather and climate. In addition, the amount of land used for salt ponds is also decreasing because a lot of salt land has been converted into settlements. Based on Badan Pusat Statistik data (Figure 2), in 2018, Indonesia's salt imports in the period (January-February 2018) reached 299,000 tons with a value of USD 9.5 million. The volume of imports rose $62 \%$ from the same period the previous year with only 184,000 tons. 


\subsection{Parangtritis Salt Potential}

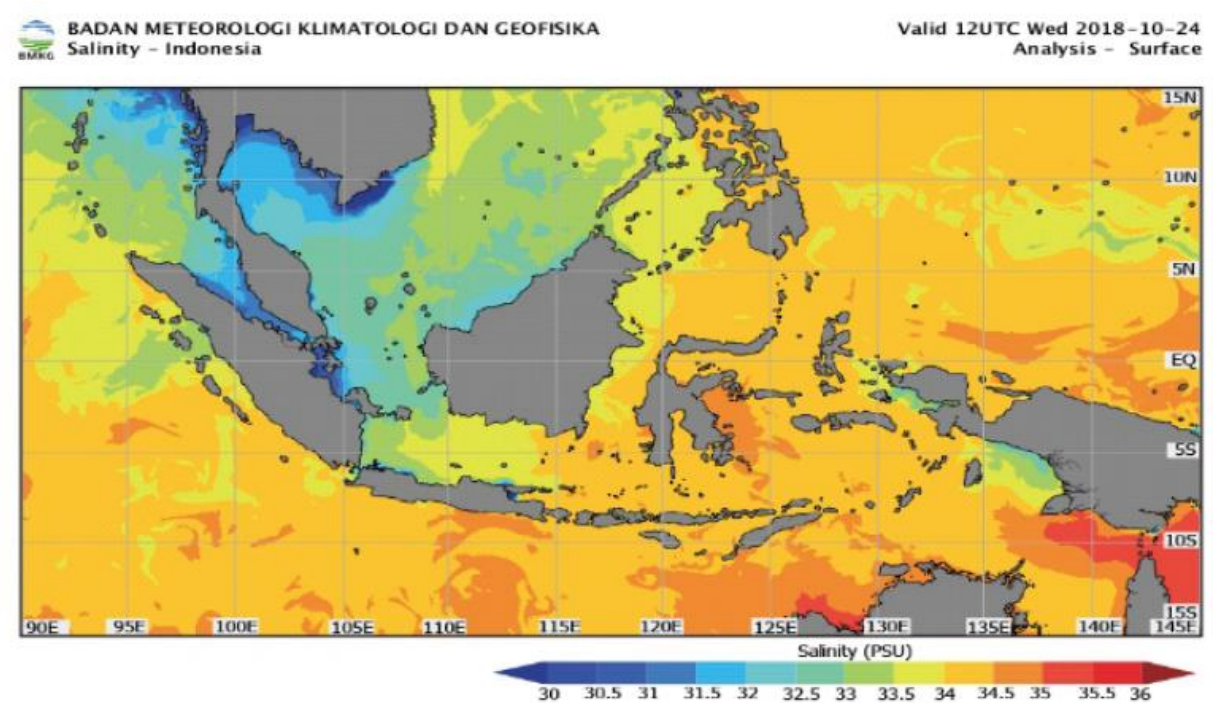

Figure 3. Indonesia Seawater Salinity Maps (BMKG, 2018).

Geographically, Parangtritis Beach is in Parangtritis Village, Bantul Subdistrict, D. I. Yogyakarta which is located at the coordinates of $7^{\circ} 59^{\prime} 15^{\prime \prime}-8^{\circ} 1^{\prime} 58^{\prime \prime}$ South Latitude and $110^{\circ} 20^{\prime} 37^{\prime \prime}$ East Longitude. (Handoyo, et al., 2017). From Figure 3 (appendix), it can be seen that Parangtritis beach, which is the southern coast of Yogyakarta, has a salinity content ranging between 34-34,5 PSU, which according to the Directorate of Coastal Community Empowerment and Business Development, sea salinity that can be used to make salt is usually it only ranges from 30-35 PSU, so it can be seen that Parangtritis beach has great potential to be developed into a national salt production center. According to Rilley (1975) with the seawater specific gravity of $\pm 1.0258 \mathrm{~kg} /$ liter obtained $\mathrm{NaCl}$ concentration of $\pm 29.6959 \mathrm{~g} / \mathrm{liter}$.

\section{Method}

The method used in this study is literature observation and data collection in the field. Literature data obtained from various sources then compiled and grouped for the design of the salt factory that utilizes low enthalpy geothermal energy in Yogyakarta. Data on geothermal energy potential is obtained based on the calculation of the geothermometer around the Parangwedang manifestation and estimation of temperature value in the reservoir rock and surface, as a form of geological and geochemical survey results. Other data obtained from observations in the field and satellite images from BMKG and Google Earth such as the distance between the sea and Parangwedang hot spring, salinity level, altitude. This study obtained a model of a salt factory that utilizes low enthalpy geothermal in Parangwedang Yogyakarta. 


\section{Result and Discussion}

\subsection{GSF (Geothermal Salt Factory) Design}

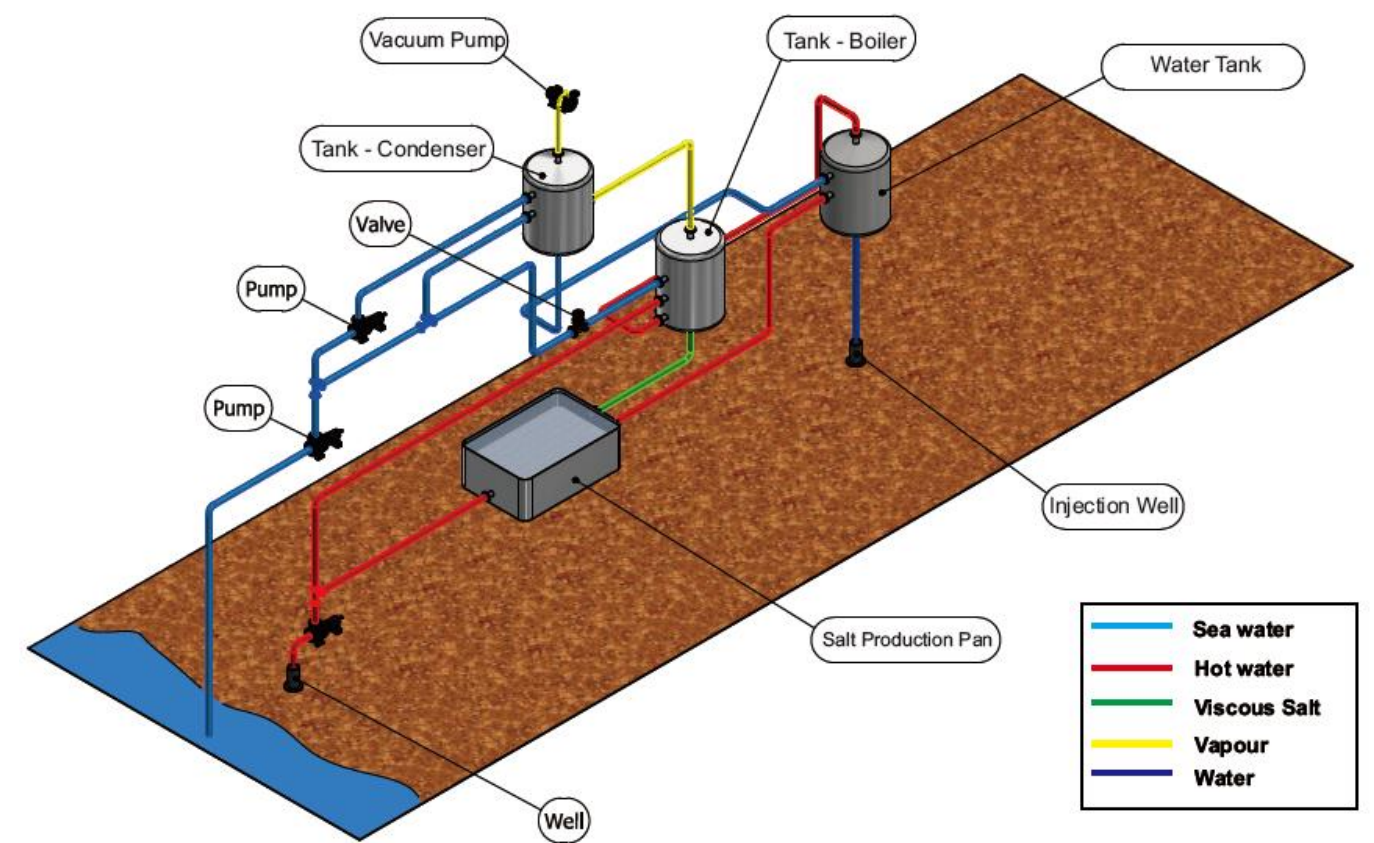

Figure 4. Schematic Diagram of GSF.

The factory design adopts basic working principles, conduction and convection using a heat exchanger (Jeong, 2018), this factory uses the evaporator (boiler/pre-heating tank) to vaporize seawater into highly viscous salt water, then the viscous solution will be deposited at a deposition site (Figure 4). Where the main processes of GSF are as follows:

1. Seawater is filtered first to remove impurities such as sand, soil, and other contaminants to ensure that only pure seawater enters the boiler (pre-heating tank).

2. After that, the water will enter the boiler where the boiler will be set to be under a pressure of $1 \mathrm{~atm}$ to reduce the boiling point of seawater at $51{ }^{\circ} \mathrm{C}$ (the boiler will be modified with a heat exchanger to transfer heat from the hot fluid to the boiler), after boiling seawater and evaporates, the boiler will make seawater with a high salt concentration.

3. Furthermore, the viscous/saturated seawater will be channeled towards the open pan which is the evaporator to be collected and deposited (open pan is also heated using continuous hot fluids).

4. After that, when seawater passes through the saturated phase, it will naturally appear on the surface of the salt crystals in the salt pan and salt can be harvested manually.

5. Then hot water that has been used will be injected to the injection well. 


\subsection{GSF (Geothermal Salt Factory) Production Capacity}

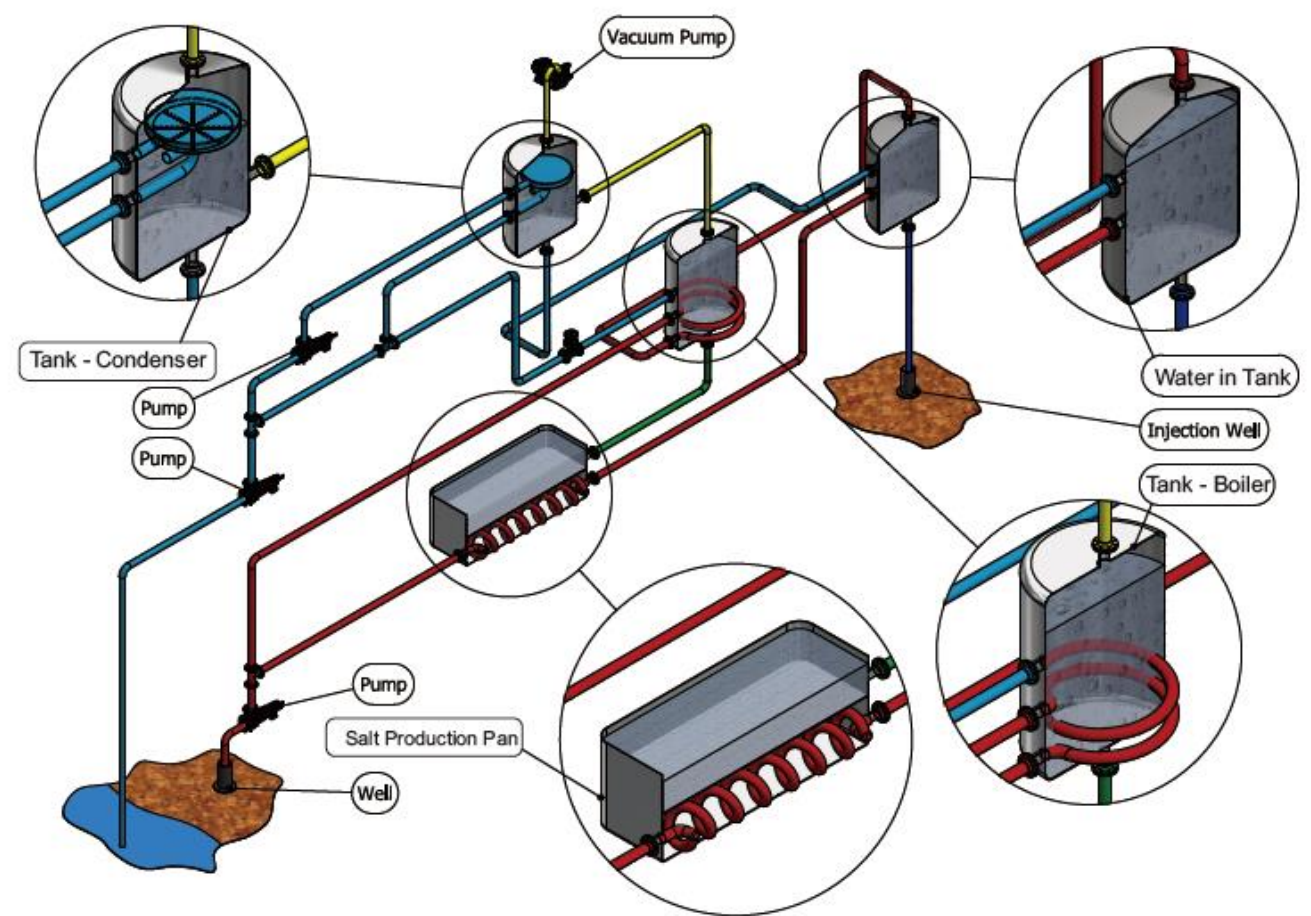

Figure 5. Components of Geothermal Salt Factory.

The working principle of a salt production pan and boiler that is modified by a heat exchanger is to move heat energy from hot water to evaporate seawater through two mechanisms, namely conduction and convection (Figure 5). The process of conduction and convection heat transfer can be explained by Fourier and Newton law equations as follows:

$$
\begin{aligned}
& q_{c}=-k A \frac{d T}{d X} \\
& q_{h}=h A\left(T_{i}-T_{O}\right)
\end{aligned}
$$

The Factory Production Capacity is calculated by determining the evaporation rate $(\mathrm{g} / \mathrm{s})$ in salt production pan, with the following equation (Akridge, 2007):

$E=$ Evaporation Rate $(\mathrm{g} / \mathrm{s})$

$$
E=\frac{q}{\alpha}
$$

$q=$ Heat Transfer Rate $(\mathrm{MJ} / \mathrm{s})$

$\alpha=$ Latent Heat $(\mathrm{MJ} / \mathrm{kg})$

Whereas $q$ is sought from Fourier law equation assuming steady state flow, the material made of copper $(k=386 \mathrm{~W} / \mathrm{mK})$, area $2 \mathrm{~m} \times 1 \mathrm{~m}$ and thickness $0.05 \mathrm{~m}$

$$
q_{c}=-k A \frac{\left(T_{o}-T_{i}\right)}{\Delta X}
$$

Where, latent heat can be determined based on equations (Akridge, 2007):

$$
\alpha=2,501-0.002361 \times T
$$

$\mathrm{T}=$ average temperature $\left({ }^{\circ} \mathrm{C}\right)$ 
Assuming the average temperature of hot water at reservoir conditions is $115^{\circ} \mathrm{C}$, then $q_{c}=10 \mathrm{MW}, \alpha$ $=2.300315 \mathrm{MJ} / \mathrm{kg}$ and evaporation rate of $E=4,347.2 \mathrm{~g} / \mathrm{s}$. After determining $E$, we can find the production capacity of GSF with equation (Akridge, 2007):

$$
m_{s}=m_{w}\left(1.52 \times 10^{-4} S+9.50 \times 10^{-3} S\right)
$$

Where $m_{s}$ is the mass $(\mathrm{kg})$ of salt crystallized, $m_{w}$ is the mass $(\mathrm{kg})$ of the water evaporated, and $\mathrm{S}$ is the initial salt concentration of the brine in $\mathrm{wt} \% \mathrm{NaCl}$. We assume that the initial salt concentration of the brine is $10 \%$, we can find that the capacity production of GSF is \pm 14 tons/year. The salt price per kilogram is IDR 12,000, It can get potential profit around IDR 168 million per year.

\subsection{SWOT Analysis}

Based on the results of data analysis that has been done with a SWOT analysis. The results are following:

a) Strength:

1. The south coast in Yogyakarta (Parangtritis and its surroundings) has great potential to be processed into quality salt because it has a salinity of 34-34.5 PSU based on BMKG Salinity Map (2018).

2. The opportunity to utilize low enthalpy geothermal energy in Indonesia is very large. Because only $5 \%$ of geothermal energy in Indonesia has been utilized.

3. The design of this salt plant does not require solar heat, so the production process will not be affected by bad weather (rainy season).

4. Salt is one of the strategic commodities in Indonesia and the demand for domestic salt consumers is very high, this demand comes from industry, cosmetics, food ingredients and

b) Weakness: even pharmaceuticals.

1. Heavy plant maintenance process due to problems such as scale and corrosion.

2. Requires large capital around USD 56,000 per well based on US Department of Energy (1977).

3. Salt farmers in Yogyakarta have long left their jobs as salt farmers because government focused on developing Parangtritis as a tourist destination.

4. The surrounding community still does not know about advanced geothermal technology.

c) Opportunity:

1. The market for salt commodities is still large. National export and industrial needs are still large.

2. Geothermal utilization and increased salt production are activities supported by the central government. The Governor of DIY representing the Regional Government even expects Jogja to produce quality salt.

3. The free trade system has also been running, providing an opportunity to get bigger consumers.

d) Threat:

1. Non-detailed regulations regarding the utilization of low enthalpy geothermal.

2. Complex business licensing.

3. Increasingly expensive maintenance costs for salt mills and tools that support this industry. 


\section{Conclusion}

From the research, it can be obtained that:

1) GSF is a modern, efficient and environmentally friendly factory that adopts two basic working principles, conduction and convection with the heat exchanger. This factory does not depend on sunlight.

2) After calculating the evaporation rate $(E)$, the estimated production capacity of salt from GSF is \pm 14 tons salt each year.

\section{References}

Akridge, G. D. (2007). Methods for calculating evaporation rates during salt production. Journal of Archaeological Science, 35, 1453-1462.

Badan Pusat Statistik. (2018). Volume dan Nilai Impor Garam Indonesia. http://databoks.katadata.co.id/datapublish/2018/03/19/kuota-impor-garam-2018-sebesar-37-jutaton.

BMKG. (2018). Salinitas. Buletin Iklim Maritim BMKG, 2(2018), 47-49.

ESDM. (2017). Potensi Panas Bumi Indonesia (Jilid 1). Direktorat Panas Bumi, Ditjen EBTKE.

Fauzi, A. (2015). Geothermal resources and reserves in Indonesia: An updated revision. Journal Geothermal Energy Science, 3, 1-6.

Handoyo, G., Agus, A. D., \& Subardjo. (2017). Peta kerawanan tsunami serta rancangan jalur evakuasi di pantai desa Parangtritis kecamatan Kretek kabupaten Bantul Daerah Istimewa Yogyakarta. Jurnal Kelautan, 10(2), 117.

Hassan, A. (2009). Mesin pengering produk pertanian bertenaga panas bumi. Jurnal Teknik Lingkungan, 10(2), 153-160.

Idral, A., E. et al. (2003). Penyelidikan terpadu geologi, geokimia dan geofisika daerah panas bumi Parangtritis. Colloquium result of inventory Event of Ministry of Mineral Resource.

Jami, A. S., Suharno, \& Netty, T. (2017). Faktor-faktor yang memengaruhi permintaan dan efektivitas kebijakan impor garam Indonesia. Buletin Ilmiah Litbang Perdagangan, 11(1), 43-68.

Jeong, Chorl. (2018). Heat exchanger. https://charliestory.tistory.com/m/35.

Juliarka, Restu, B., \& Niasari, S. W. (2016). Geothermal exploration using geochemical data; Study case: Parang Wedang geothermal field, Indonesia. AIP Conference Proceedings (2016).

Riley, J. P. (1975). Analytical chemistry of sea water. Chemical oceanography, (v.3., pp. 193-514). Academic Press London.

US Department of Energy (1977). Applications of geothermal resources in the evaporation and crystallization industry. Final Report October 1977 